\title{
Testicular Superoxide Dismutase Activity, Heat Shock Protein 70 Concentration and Blood Plasma Inhibin- $\alpha$ Concentration of Dogs with a Sertoli Cell Tumor in a Unilateral Cryptorchid Testis
}

\author{
Eiichi KAWAKAMI ${ }^{1) *}$, Taichi HIRANO ${ }^{1)}$, Tatsuya HORI ${ }^{1)}$ and Toshihiko TSUTSUI $^{1)}$ \\ ${ }^{1)}$ Laboratory of Veterinary Reproduction, Nippon Veterinary and Life Science University, 1-7-1 Kyonan-cho, Musashino-shi, \\ Tokyo 180-8602, Japan
}

(Received 19 February 2007/Accepted 24 August 2007)

ABSTRACT. The proportions of Sertoli cell tumor (SCT), seminoma and Leydig cell tumor in 50 dogs with unilateral testicular tumors were $52 \%, 36 \%$ and $12 \%$, respectively. The rate of occurrence of SCT in the cryptorchid testis was very high (71\%). The testicular superoxide dismutase (SOD) activity, testicular heat shock protein (HSP) 70 concentration and peripheral blood plasma inhibin (INH)- $\alpha$ concentration of 10 dogs with a unilateral cryptorchid testis and no testicular tumors, 10 dogs with SCT in a unilateral cryptorchid testis and 10 normal dogs, all aged 5-15 years, were measured in order to identify high risk factors for the occurrence of SCT in the canine cryptorchid testis. The mean SOD activity in cryptorchid testes and SCTs was significantly lower and higher, respectively, than in normal testes (both $\mathrm{P}<0.01$ ). The mean HSP 70 concentration in both cryptorchid testes and SCTs was significantly higher than in normal testes (both $\mathrm{P}<0.01$ ). The mean plasma INH- $\alpha$ concentration of the cryptorchid and SCT dogs was significantly lower and higher, respectively, than in normal dogs $(\mathrm{P}<0.05$ and 0.01 , respectively). The low SOD activity in the cryptorchid testis, low blood plasma INH- $\alpha$ concentration of the cryptorchid dogs and high HSP 70 concentration in the SCTs may be related to the occurrence of SCT and tumor cell proliferation in canine cryptorchid testes.

KEY WORDS: canine, HSP 70, inhibin- $\alpha$, Sertoli cell tumor, SOD.

J. Vet. Med. Sci. 69(12): 1259-1262, 2007

The prevalence of testicular tumors is higher in dogs than in any other mammalian species examined $[5,9]$. The main types of tumors are Sertoli cell tumor (SCT), seminoma and Leydig cell tumor $[5,15]$, and the occurrence rate of SCT in the cryptorchid testes of dogs is known to be much higher than in scrotal testes [14, 26].

A higher temperature in experimental cryptorchid testes in rats has been found to cause high production of reactive oxygen species (ROS) as a result of a reduction in superoxide dismutase (SOD) activity in the testicular tissue [1, 29]. A high ROS concentration in the cryptorchid testis is an important risk factor for the occurrence and development of testicular tumors [29]. Heat shock protein (HSP) 70 is the main protein produced abundantly in some tissues exposed to heat stress [22], and it induces the development of certain tumors $[6,18,20]$. Inhibin $(\mathrm{INH})$ in male animals is a glycoprotein produced by Sertoli cells [23, 24, 28] and is composed of two subunits, an $\alpha$-unit and a $\beta$-unit $[8,23]$. The bioactivity of INH- $\alpha$ is important for spermatogenesis in the testis $[11,24,29]$ and is especially correlated with Sertoli cell function $[19,21]$. The blood plasma INH concentration is lower in cryptorchid men than in normal men [3, 7, 21], and the rate of occurrence of SCT has been found to be markedly higher in knockout mice with INH- $\alpha$ gene deficiency [4].

In the present study, the proportion of SCTs was investi-

\footnotetext{
* Correspondence to: Kawakami, E., Laboratory of Veterinary Reproduction, Nippon Veterinary and Life Science University, 1-7-1 Kyonan-cho, Musashino-shi, Tokyo 180-8602, Japan. e-mail: kawakami@nvlu.ac.jp
}

gated in dogs. The testicular SOD activity and HSP 70 concentration and blood plasma INH- $\alpha$ concentration of dogs with a unilateral cryptorchid testis, dogs with an SCT in a unilateral cryptorchid testis and normal dogs were measured to identify the high risk factors for the occurrence of SCT in canine cryptorchid testes.

\section{MATERIALS AND METHODS}

Samples of testes and blood: The testes of 50 dogs diagnosed with a unilateral testicular tumor in the scrotal or cryptorchid testes were obtained immediately after orchidectomy at the Animal Medical Center of Nippon Veterinary and Life Science University and seven small clinics in Tokyo between April 2002 and September 2004. A sample of tumor material was fixed in Bouin's solution, and the tumors were classified histopathologically, according to previous reports concerning canine testicular tumors $[5,15]$, by examination of sections stained with PAS and hematoxylin. The remaining testicular tissue was stored at $-80^{\circ} \mathrm{C}$.

Testicular tumor tissue diagnosed as SCT tumor was left for $30 \mathrm{~min}$ at room temperature, and then the tissue $(40 \mathrm{mg})$ was homogenized in $4 \mathrm{~m} l$ of phosphate buffered solution (40 mM Na $2 \mathrm{HPO}_{4} \bullet 12 \mathrm{H}_{2} \mathrm{O}, 2 \mathrm{mM} \mathrm{KH} \mathrm{PO}_{4}, 150 \mathrm{mM} \mathrm{NaCl}$ and $3 \mathrm{mM} \mathrm{KCl}$ ) using an ultra tissue homogenizer. The suspension was then centrifuged for $30 \mathrm{~min}$ at $11,000 \mathrm{~g}$ (at $4^{\circ} \mathrm{C}$ ), and the supernatant was used to measure the SOD activity and HSP 70 concentration.

Heparinized peripheral blood samples $(5 \mathrm{~m} l)$ were collected from the 50 dogs with testicular tumors before 
orchidectomy. The blood was immediately centrifuged for $15 \mathrm{~min}$ at $1,200 \mathrm{~g}\left(\right.$ at $4^{\circ} \mathrm{C}$ ), and the obtained plasma was stored at $-20^{\circ} \mathrm{C}$ until measurement of the INH- $\alpha$ concentration.

A peripheral blood sample $(5 \mathrm{~m} l)$ and both testes were obtained from 10 unilaterally cryptorchid dogs that did not have a testicular tumor (6-12 years old) and 10 normal dogs (5-13 years old) at the above-mentioned animal hospitals and stored at $-80^{\circ} \mathrm{C}$ and $-20^{\circ} \mathrm{C}$, respectively.

Measurement of testicular SOD activity and HSP 70 concentration: SOD activity and the HSP 70 concentration in the supernatant of the testicular and SCT tissues were measured by enzyme analysis reactions with an SOD Assay Kit (Trevigen Inc., MD, U.S.A.) and with an HSP 70 ELISA Kit (Stressgene Biotechnologies Inc., BC, Canada), respectively. The sensitivities of the kits were $0.01-100 \mathrm{unit} / \mathrm{mg}$ SOD per assay tube and $0.01-50 \mu \mathrm{g} / \mathrm{mg}$ HSP per assay tube, respectively. A spectrophotometer was used at an absorbance of $550 \mathrm{~nm}$ for both assays. The total protein concentration of each sample was determined with a Protein Assay Kit (Bio-Rad Laboratories Inc., CA, U.S.A.) in order to calculate SOD units/mg protein and HSP $70 \mu \mathrm{g} / \mathrm{mg}$ protein.

Measurement of the blood plasma INH- $\alpha$ concentration: The blood plasma INH- $\alpha$ concentration was measured by an enzyme immunoassay method using an INH- $\alpha$ Assay Kit (Peninsula Laboratories Inc., CA, U.S.A.). A spectrophotometer was used at an absorbance of $570 \mathrm{~nm}$ for this assay.

Statistical analysis: The data are presented as mean values \pm standard error $( \pm$ SE). Differences between means were statistically analyzed by Student's $t$-test. P-values of $<0.05$ were regarded as significant.

\section{RESULTS}

Rates of occurrence of testicular tumors: The proportions of SCT, seminoma and Leydig cell tumors in all 50 dogs with a unilateral testicular tumor and the rates of occurrence of each tumor in the cryptorchid testes are shown in Table 1. The rate of occurrence of SCT was the highest among the 3 types of canine testicular tumor. The rate of SCT in cryptorchid testes was very high $(71.4 \%)$.

Testicular SOD activity: The mean $( \pm \mathrm{SE})$ testicular SOD activities of the unilaterally cryptorchid dogs without a testicular tumor, the dogs with an SCT in the cryptorchid testis and the normal dogs are shown in Table 2. The mean SOD activity of the cryptorchid testes was significantly lower than in the contralateral scrotal testes of the cryptorchid dogs and testes of the normal dogs (both $\mathrm{P}<0.01$ ). The mean SOD activity of SCTs was significantly higher than in the contralateral scrotal testes of the dogs with an SCT in the unilateral cryptorchid testis and the testes of the normal dogs (both $\mathrm{P}<0.01$ ).

Testicular HSP 70 concentration: The mean ( \pm SE) testicular HSP 70 concentrations of the unilaterally cryptorchid dogs without a testicular tumor, the dogs with an SCT in the cryptorchid testis and the normal dogs are shown in Table 3. The mean HSP 70 concentrations in the cryptorchid testes and SCTs were significantly higher than in the contralateral

Table 1. Rates of occurrence of Sertoli cell tumor, seminoma and Leydig cell tumor in dogs $(\mathrm{n}=50,6-15$ years old) with a unilateral testicular tumor and rates (\%) of each tumor in cryptorchid (CR) and scrotal testes

\begin{tabular}{lccc}
\hline & Rates in all dogs & CR testes & Scrotal testes \\
\hline Sertoli cell tumor & $52.0(26 / 50)$ & $71.4(20 / 28)$ & $27.3(6 / 22)$ \\
Seminoma & $36.0(18 / 50)$ & $28.6(8 / 28)$ & $45.4(10 / 22)$ \\
Leydig cell tumor & $12.0(6 / 50)$ & $0(0 / 28)$ & $27.3(6 / 22)$ \\
\hline
\end{tabular}

Table 2. Mean ( \pm SE) testicular superoxide dismutase activities (units/mg protein) of normal dogs ( $\mathrm{n}=10,5-13$ years old), unilaterally cryptorchid $(\mathrm{CR})$ dogs $(\mathrm{n}=10,6-12$ years old) and dogs with a Sertoli cell tumor in a CR testis ( $\mathrm{n}=10,6-15$ years old)

\begin{tabular}{ccccccc}
\hline Normal dogs & & \multicolumn{2}{c}{ CR dogs } & & \multicolumn{2}{c}{ Dogs with a Sertoli cell tumor } \\
\cline { 1 - 1 } \cline { 5 - 6 } Normal testes & & CR testes & Scrotal testes & & CR tumor testes & Scrotal testes \\
\hline $0.38 \pm 0.08$ & & $0.07 \pm 0.03^{* *}$ & $0.22 \pm 0.05$ & & $0.59 \pm 0.06^{* *}$ & $0.18 \pm 0.05$ \\
\hline
\end{tabular}

** $\mathrm{P}<0.01$, compared with normal testes and contralateral scrotal testes.

Table 3. Mean $( \pm \mathrm{SE})$ testicular heat shock protein 70 concentrations $(\mu \mathrm{g} / \mathrm{mg}$ protein $)$ of normal dogs ( $\mathrm{n}=10,5-13$ years old), unilaterally cryptorchid (CR) dogs ( $\mathrm{n}=10,6-12$ years old) and dogs with a Sertoli cell tumor in a CR testis $(\mathrm{n}=10,6-15$ years old)

\begin{tabular}{|c|c|c|c|c|}
\hline \multirow{2}{*}{$\begin{array}{l}\text { Normal dogs } \\
\text { Normal testes }\end{array}$} & \multicolumn{2}{|c|}{ CR dogs } & \multicolumn{2}{|c|}{ Dogs with a Sertoli cell tumor } \\
\hline & CR testes & Scrotal testes & CR tumor testes & Scrotal testes \\
\hline $0.24 \pm 0.01$ & $0.79 \pm 0.24 *, * *$ & $0.28 \pm 0.02$ & $0.89 \pm 0.25 *, * *$ & $0.27 \pm 0.03$ \\
\hline
\end{tabular}

${ }^{*} \mathrm{P}<0.05$, compared with contralateral scrotal testes. ${ }^{* *} \mathrm{P}<0.01$, compared with normal testes. 
Table 4. Mean ( \pm SE) peripheral blood plasma inhibin- $\alpha$ concentrations $(n \mathrm{~g} / \mathrm{m} l)$ of normal dogs $(\mathrm{n}=10,5-13$ years old $)$, unilateral cryptorchid (CR) dogs $(\mathrm{n}=10,6-12$ years old $)$ and dogs with a Sertoli cell tumor in a CR testis $(\mathrm{n}=10,6-15$ years old)

\begin{tabular}{ccc}
\hline Normal dogs & CR dogs & Dogs with a Sertoli cell tumor \\
\hline $2.23 \pm 0.42$ & $1.28 \pm 0.24^{*}$ & $5.74 \pm 1.36^{* *}$ \\
\hline
\end{tabular}

$* \mathrm{P}<0.05$ and $* * \mathrm{P}<0.01$, compared with normal dogs.

scrotal testes (both $\mathrm{P}<0.05$ ) and testes of the normal dogs $(\mathrm{P}<0.01)$.

Peripheral blood plasma INH- $\alpha$ concentration: The mean $( \pm \mathrm{SE})$ peripheral blood plasma INH- $\alpha$ concentrations of the unilaterally cryptorchid dogs without a testicular tumor, the dogs with an SCT in the cryptorchid testis, and the normal dogs are shown in Table 4. The mean INH- $\alpha$ concentration of the cryptorchid dogs was significantly lower than in the normal dogs $(\mathrm{P}<0.05)$. The mean INH- $\alpha$ concentration of the dogs with an SCT was significantly higher than in the normal dogs $(\mathrm{P}<0.01)$.

\section{DISCUSSION}

The results of this study confirmed a high rate of occurrence of SCT in the cryptorchid testes of dogs as shown in other reports $[15,26]$ and confirmed that the mean SOD activity of the canine cryptorchid testes is low, as shown in the experimental cryptorchid testes of rats [1, 10, 29]. Because the activity of many enzymes, including SOD, in cryptorchid testes is very low as a result of the higher temperature of the retained abdominal or inguinal position than the scrotum, an increased ROS concentration has been reported in cryptorchid testes [1, 29]; an increased testicular ROS concentration is a high risk factor for the occurrence and development of certain tumors [29]. However, the mean SOD activity of the SCTs was higher than in normal testes. The SOD activity of human ovarian tumors [16] has been reported to increase markedly. The high SOD production of SCTs is thought to be caused by abnormal tumor cell function.

The mean HSP concentration of the canine cryptorchid testes in the present study was very high. High temperature or heat stress has been found to induce an increase in HSP protein production in certain tissues [22]. HSP 70 stimulates proliferation of some types of tumor cells [6], and it has been found to be an anti-apoptotic protein that inhibits cell death by apoptosis in human and canine mammary gland tumor cells [18] and human prostatic adenocarcinama cells [20]. The high level of HSP 70 in canine SCTs maintains the viability and development of tumor cells.

INH has been reported to be mainly produced by Sertoli cells in the testes of many animals species [2, 23, 24, 28], including dogs [12]. The blood plasma INH concentration of cryptorchid men [3, 7, 21] and experimental cryptorchid rats [27] has been found to be lower than in normal men and rats. The authors have reported lower Sertoli cell function in experimental cryptorchid testes from dogs than in the contralateral scrotal testes [17]. In the present study the mean blood plasma INH- $\alpha$ concentration of the congenitally cryptorchid dogs was lower than in the normal dogs. Since the INH concentration in the testis is correlated with Sertoli cell function [19,21], the Sertoli cell function of the congenital cryptorchid testes in dogs is assumed to be poor. The rate of occurrence of SCT has been found to be markedly higher in knockout mice with INH- $\alpha$ gene deficiency [4], and INH- $\alpha$ may play a role in inhibiting the development of SCT in dogs. The low INH- $\alpha$ concentration in the blood plasma of dogs with a cryptorchid testis is assumed to be a risk factor for the occurrence of SCT. However, it has already been reported that SCT cells produce a large amount of INH [8] and that the blood plasma INH concentration of dogs with SCT is very high $[13,25]$, as found in the present study. Abnormal function of SCT cells is thought to cause markedly high INH- $\alpha$ production.

Based on the above, the low SOD activity in the canine cryptorchid testis may induce occurrence of testicular tumors, and the low INH- $\alpha$ concentration in blood plasma may be an especially important factor in the occurrence of SCT. A high HSP 70 concentration in the cryptorchid testis is assumed to accelerate proliferation of SCT cells.

\section{REFERENCES}

1. Ahotupa, M. and Huhtaniemi, I. 1992. Impaired detoxification of reactive oxygen and consequent oxidative stress in experimentally cryptorchid rat testis. Biol. Reprod. 46: 1114-1118.

2. Bohring, C. and Krause, W. 2003. Serum levels of inhibin B in men of different age groups. Aging Male 6: 73-78.

3. Christiansen, P., Andersson, A.M., Skakkebaek, N.E. and Juul, A. 2002. Serum inhibin B, FSH, LH and testosterone levels before and after human chorionic gonadotropin stimulation in prepubertal boy with cryptorchidism. Eur. J. Endocrinol. 147: 95-101.

4. Cipriano, S.C., Chen, L., Burns, K.H., Koff, A. and Matzuk, M.M. 2001. Inhibin and p27 interact to regulate gonadal tumorigenesis. Mol. Endocrinol. 15: 985-996.

5. Cohen, D., Reif, J.S., Brodey, R.S. and Keiser, H. 1974. Epidemiological analysis of the most prevalent sites and types of canine neoplasia observed in a veterinary hospital. Cancer Res. 34: 2859-2868.

6. Daugaad, M., Jaattela, M. and Rohde, M. 2005. Hsp70-2 is required for tumor cell growth and surval. Cell Cycle 4: 877880.

7. De Gouveia Brazao, C.A., Pierik F.H., Erenpreiss, Y., De Jong, F.H., Dohle, G.R. and Weber, R.F. 2003. The effect of cryptorchidism on inhibin B in a subfertile population. Clin. Endocrinol. 59: 136-141.

8. De Jong, F.H., Grootenhuis, A.J., Steenbergen, J., Van Sluijs, F.J., Foekens, J.A., Ten Kate F.J., Oosterhuis, J.W., Lamberts, S.W. and Klijn, J.G. 1990. Inhibin immunoreactivity in gonadal and non-gonadal tumors. J. Steroid Biochem. Mol. Biol. 37: 863-866.

9. Dow, C. 1962. Testicular tumor in the dog. J. Comp. Path. 72: 247-265.

10. Fei, Q.J., Zheng, X.M., Li, S.W. and Zheng, H. 2002. The effect of antioxidant enzyme on germ cell apoptosis in cryp- 
torchidism. Zhonghua. Nan. Ke. Xue. 8: 255-257.

11. Fujimura, S., Hondo, E., Kobayashi, T., Watanabe, G., Taya, K., Kitamura, N. and Yamada, J. 1998. Expression of inhibin $\alpha$-subunit in horse testis. J. Vet. Med. Sci. 60: 937-942.

12. Garde, S.V., Moodbidri, S.B. and Sheth, A.R. 1989. Localization of inhibin in testes of human, bonnet monkey, dog and rat by immunoperoxidase technique. Indian J. Exp. Biol. 27: 404407.

13. Grootenhuis, A.J., van Sluijs, F.J., Klaij, I.A., Steenbergen, J., Timmerman, M.A., Bevers, M.M., Dieleman, S.J. and De Jong, F.H. 1990. Inhibin, gonadotrophins and sex steroids in dogs with Sertoli cell tumours. J. Endocrinol. 127: 235-242.

14. Hayes, H.M., Wilson, G.P., Pendergrass, T.W. and Cox, V.S. 1985. Canine cryptorchidism and subsequent testicular neoplasia: Case-control study with epidemiologic update. Teratology 32: $51-56$.

15. Howard, M., Hayes, J. and Thomas, W.P. 1976. Canine testicular tumors: Epidemiologic features of $410 \mathrm{dogs}$. Int. J. Cancer 18: $482-487$.

16. Hu, Y., Rosen, D.G., Zhou, Y., Feng, L., Yang, G., Liu, J. and Huang, P. 2005. Mitochondrial MnSOD expression in ovarian cancer: Role in cell proliferation and response to oxidative stress. J. Biol. Chem. 280: 39485-39492.

17. Kawakami, E., Hori, T. and Tsutsui, T. 1999. Function of contralateral testis after artificial unilateral cryptorchidism in dogs. J. Vet. Med. Sci. 61: 1107-1111.

18. Kumaraguruparan, R., Karunagaran, D., Balachandran, C., Manohar, B.M. and Nagini, S. 2006. Of humans and canines: A comparative evaluation of heat shock and apoptosis-associated proteins in mammary tumors. Clin. Chim. Acta 365: 168-176.

19. Luisi, S., Florio, P., Reis F.M. and Petraglia, F. 2004. Inhibins in female and male reproductive physiology: Role in gametogenesis, conception, implantation and early pregnancy. Hum. Reprod. Update 11: 123-135.

20. Mambula, S.S. and Calderwood, S.K. 2006. Heat shock protein
70 is secreted from tumor cells by a nonclassical pathway involving lysosomal endosomes. J. Immunol. 177: 7849-7857.

21. Medras, M., Trzmiel, A., Grabowski, M., Bohdanowicz-Pawlak and Zagodzka, E. 2005. Inhibin B: A marker of the function of male gonad. Ginekol. Pol. 76: 484-490.

22. Nollen, A.A.E., Brunsting, F.J., Roelofsen, H., Weber, A.L. and Kampinga, H.H. 1999. In vivo chaperone activity of heat shock protein and thermotolerance. Mol. Cell Biol. 19: 20692079.

23. O'Connor, A.E. and De Kretser D.M. 2004. Inhibins in normal male physiology. Semin. Reprod. Med. 22: 177-185.

24. Okuma, Y., O'Connor, A.E., Hayashi, T., Loveland, K.L., De Kretser, D.M. and Hedger, M.P. 2006. Regulated production of activin A and inhibin B throughout the cycle of the seminiferous epithelium in the rat. J. Endocrinol. 190: 331-340.

25. Peters, M.A., De Jong, F.H., Teerds, K.J., De Rooij, D.G., Dieleman, S.J. and Van Sluijs, F.J. 2000. Ageing, testicular tumours and the pituitary-testis axis in dogs. J. Endocrinol. 166: $153-161$.

26. Reif, J.S. and Brodey, R.S. 1969. The relationship between cryptorchidism and canine testicular neoplasia. J. Am. Vet. Med. Assoc. 155: 2005-2010.

27. Ren, L., Medan, M.S., Ozu, M., Li, C., Watanabe, G. and Taya, K. 2006. Effects of experimental cryptorchidism on sperm motility and testicular endocrinology in adult male rats. $J$. Reprod. Dev. 52: 219-228.

28. Weng, Q., Medan, M.S., Xu, M., Tsubota, T., Watanabe, G. and Taya, K. 2006. Seasonal changes in immunolocalization of inhibin/activin subunits and testicular activity in wild male raccoon dogs (Nyctereutes procyonoides). J. Reprod. Dev. 52: 503-510.

29. Zini, A. and Schlegel, P.N. 1997. Cu/Zn superoxide dismutase, catalase and glutathione peroxidase mRNA expression in the rat testis after surgical cryptorchidism and efferent duct ligation. J. Urol. 158: 659-663. 